\title{
Influence of Agricultural Land Use Change on the Selected Physico-Chemical Soil Properties in Kilombero Valley Floodplain, Southeastern Tanzania
}

\author{
Nangware Kajia Msofe ${ }^{1,2,3}$, Lianxi Sheng1,3* ${ }^{1, Z h e n x i n ~ L i}{ }^{1,3 *}$, Lyimo J ${ }^{4}$ and Lingyan Wang ${ }^{1,3}$ \\ ${ }^{1}$ State Environmental Protection Key Laboratory of Wetland Ecology and Vegetation Restoration, Northeast Normal University \\ ${ }^{2}$ Department of Environmental Studies, The Open University of Tanzania, Tanzania
}

${ }_{3}^{3}$ Jilin Provincial Key Laboratory of Ecological Restoration and Ecosystem Management, China

${ }^{4}$ Institute of Resources Assessment, University of Dar es Salaam, PTanzania

Submission: September 23, 2019; Published: October 04, 2019

*Corresponding author: Lianxi Sheng, State Environmental Protection Key Laboratory of Wetland Ecology and Vegetation Restoration, Northeast Normal University, Changchun 130024 \& Jilin Provincial Key Laboratory of Ecological Restoration and Ecosystem Management, Changchun 130117, China

\section{Abstract}

Land use change attributed to increased population pressure, government policies, economic development, and biophysical factors has affected the soil properties, which plays an important role in agricultural productivity. Thus, this study investigated the effects of changes in land use on some selected soil physicochemical properties in the Kilombero valley floodplain, Tanzania. Soils were collected from the pristine wetland, forest, upland cultivation, and rice farm. The agricultural land considered for this study has been converted from forest and wetland, and under cultivation for over 10 years. The total of 48 soil samples were collected from depth of $0-20 \mathrm{~cm}$ and $20-40 \mathrm{~cm}$ to investigate the variance of cation exchange capacity (CEC), total organic matter (TOM), total nitrogen (TN), soil pH, bulk density (BD), total phosphorus (TP), soil moisture content (SMW) and water stable aggregates (WSA) in the four selected land use types. The two-way analysis of variance (ANOVA) was employed. The results showed that TOM, TN, CEC, SMC, and WSA have significantly decreased (p-value, <0.05) while BD, soil pH and TP have significantly increased ( $p$-value, $<0.05$ ) as the forest and wetland converted to upland cultivation and rice farm, respectively. Moreover, Post Hoc Test of LSD revealed that there is a significant difference at $\mathrm{P}<0.05$ for all the selected soil physicochemical properties between wetland and rice farm, showing that the wetland is highly sensitive to declining soil fertility, particularly organic matter. Therefore, this study recommends the imposition of agricultural practices such as agro forestry, incorporation of crop residues, the use of organic manures, minimum tillage, and crop rotation to facilitate soil organic matter building up. Moreover, to reduce the encroachment of farmers into wetland and forest area serious attention should be given to the development of sustainable land use planning and management in the Kilombero valley floodplain.

Keywords: Soil fertility; Agricultural land use change; Soil physico-chemical properties; Kilombero valley floodplain; Tanzania

Abbreviations: CEC: Cation exchange capacity; TOM: Total Organic Matter; TN: Total Nitrogen; BD: Bulk Density; TP: Total Phosphorus; SMC: Soil Moisture Content; WSA: Water Stable Aggregates; MWD: Mean Weighted Diameter

\section{Introduction}

The land use change is associated with agricultural expansion and intensification, deforestation and expansion of human settlement caused by increased population pressure, government policies, economic development and biophysical factors such as climate change and variability $[1,2]$. During the last decades, wetlands in the globe have been degraded due to agricultural land use change [3-5]. The intensification of agriculture land use into the wetland is attributed to the increased dependence on the wetland for food security and human livelihood [6]. For instance, in East Africa, it was revealed that wetlands provide about $10-40 \%$ of the annual food to the rural population [7]. Moreover, wetlands are considered to have higher production potential and persistent to global climate change, making it a resistant ecosystem than upland ecosystems [6]. These land use changes have considerable effect on the dynamics of the soil properties resulting in soil deg- 
radation and loss [8-10]. Land use change from pristine wetland into farmland may reduce water availability and organic residues that lead to a decline in soil fertility [11], increased rate of erosion [12], the loss of soil organic matter and nutrients [13], and associated wetland drainage that accelerated rate of soil degradation $[10,13,14]$. Moreover, removal of vegetation cover such as forest, woodland to agricultural land affects soil nutrients. In study by [15] observed an increase in bulk density and decreased in SOM, total nitrogen (TN), exchangeable cations and cation exchange capacity (CEC) contents following the conversion of forest into farmland. [16] indicated that deforestation has resulted in the deterioration of SOM in the soil. The study by [17] indicated that the clearing of the hardwood forest and tillage practices during 40 years in Golestan Province, Iran has lead to a decrease in SOC by $71.5 \%$, affecting soil fertility in the area. Moreover, agricultural land use change may also affect biological properties such as soil enzyme activities, which is a more significant indicator of soil quality than physical and chemical properties [18]. This is due to the fact that soil biological properties can provide quantitative information on soil chemical processes, nutrient mineralization rates, and organic matter accumulation [19]. Therefore, understanding the dynamics of soil nutrients and fertility on different land use types will provide basic information that will help mitigate continuous soil degradation due to land use changes in various ecosystems, particularly wetland.

Tanzania has potential four sites designated as the wetland of International importance with surface size namely Malagarasi-Muyovozi (3 250 000ha), Lake Natron Basin (224 781ha), Kilombero Valley Floodplain (KVFP) (796 735ha) and Rufiji-Mafia Kilwa (596 906ha) [20]. It is estimated that wetland occupies $10 \%$ of Tanzania's land surface, extremely rich in wetlands ranging from coastal marine to freshwater wetlands [21]. Studies that based on remote sensing and GIS analysis have shown that in the Kilombero valley floodplain agricultural land has increased by $11.3 \%$ while the forest and wetland decreased by $10.3 \%$ and 4.6\%, respectively from 1990 to 2016 implying deforestation and wetland conversion to agricultural land, predominantly rice paddy [22]. These changes in land use and the intensification of human activities such as cattle grazing, irrigation and slash, and burning have severely affected the soil condition particular, soil carbon is of serious concern [23]. Therefore, this study aims to analyze the effects of agricultural land use change on soil physical and chemical properties in the Kilombero valley floodplain, Tanzania. The study on the effect of agricultural land use on soil properties has focused on soil moisture content, bulk density (BD), water stable aggregates (WSA), total organic matter (TOM), total nitrogen (TN), soil pH, total phosphorus (TP), and cation exchange capacity (CEC) in two soil depths of the four selected land use systems; pristine wetland, forest, upland cultivation and rice farm.

\section{Materials and Methods}

\section{Study sites description}

The study was conducted at Mofu and Mbigu wards in Kilombero valley floodplain that lies between Latitude $10^{\circ} 00^{\prime} \mathrm{S}-08^{\circ} 40^{\prime} \mathrm{S}$ and Longitude $37^{\circ} 10^{\prime}-35^{\circ} 10^{\prime} \mathrm{E}$, administratively the valley falls in Kilombero, Ulanga and Malindi districts, Morogoro region in Southeastern Tanzania (Figure 1). The valley runs south-west to north-east, joining Selous Game Reserve in the east covering an area of about $30,700 \mathrm{~km}^{2}$ [24]. It contains the seasonal floodplain at around $200 \mathrm{~m}$ above sea level that covers an area of $7967 \mathrm{~km}^{2}$ representing the largest inland freshwater wetland in East Africa situated in low elevation. The valley has a sub-humid tropical climate with bimodal rainfall with an annual average between 1200 and $1400 \mathrm{~mm}$ with a period of short rains between December and February and long rains between March and May; and a mean annual temperature of $23^{\circ} \mathrm{C}$ to $25^{\circ} \mathrm{C}$ [25].

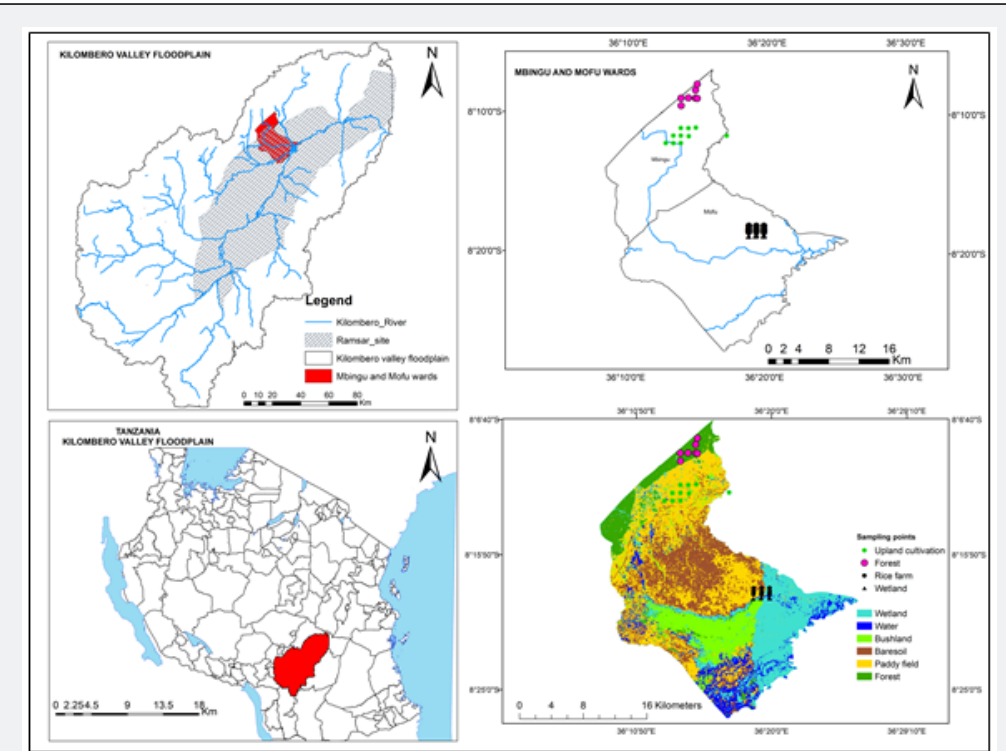

Figure 1: The location map of the Kilombero valley floodplain, southeastern Tanzania and sampling points. 


\section{Drainage, geology and soils}

The valley is divided by River Kilombero that begins at the south-west side where Mpanga, Mnyera and Ruhuji rivers enter the valley [26]. Important tributaries on the western bank of the Kilombero are Kihansi, Mngeta, Ruipa, Lumemo, and Msolwa [27]. River Ruipa passes through the study area, while Kihansi is located few kilometers south of the study site. Geologically the valley is described by sedimentary basin infillings forming a seasonal alluvial floodplain. According to the Harmonized World Soil Database (HWSD) [28] the dominating soils in the low level of the Kilombero valley are Cambic Arenosois, Eutric-Gleyic Fluvisols and Humic-Gleyic Fluvisols, whereas the uplands are predominantly covered by Haplic Acrisols and Umbric Nitisols. Moreover, in the high altitudes of the western parts of the Kilombero valley Haplic Lixisols and Umbric Acrisol dominate and in the lower altitudes of the eastern Kilombero valley mainly Chromi-Ferralic Cambisols and Ferralic Cambisols are found (Figure 2).

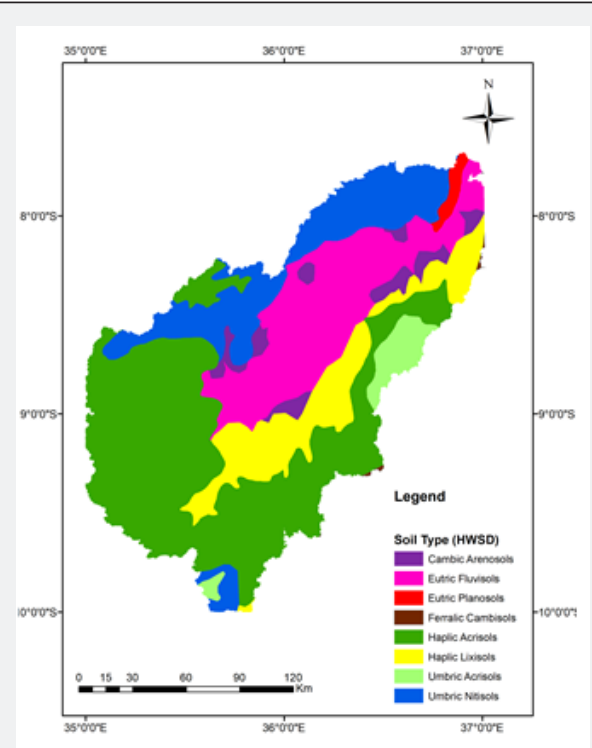

Figure 2: Soil types distribution in the Kilombero valley floodplain, southeastern Tanzania according to the Harmonized World Soil Database [28].

\section{Natural vegetation and socio-economic activities}

The vegetation habitat of the KVFP forms a gradient from high altitude to the Kilombero River, where it starts with tropical rainforests, bushlands, and wooded grasslands, with some patches of agricultural fields. The valley contains the seasonal floodplain in the low altitude, which is characterized by rainfed lowland rice cultivation during the rainy season dominated with grassland vegetation, such as Hyparrhenia spp., Panicum fluviicola Steud., and Phragmites mauritianus Kunth. The fringes of the Kilombero river successively change from grassland to Miombo woodland characterized by species of Brachystegia and Julbernardia towards the upper Kilombero valley floodplain. The main socio-economic activities in the Kilombero valley floodplain area are namely small scale rain-fed and subsistence farming, livestock keeping, and fishing. The main crop grown includes sugarcane (Saccharum officinarum), maize (Zea mays), rice paddy (Oryza sativa), cassava (Manihot esculata), sesame and more recently banana.

\section{Soil sampling design and collection}

Soil samples were collected in August 2018 from six locations in each of the four land use types (pristine wetland, forest, upland cultivation, and rice farms). The agricultural land considered for this study has been converted from forest and wetland and has been under cultivation for over 10 years. Upland cultivation involved the farmland of maize, cassava, cocoa, sesame, and banana, which was transformed from the forest. The rice farms involved in sample collection were the adjust converted wetland to rice paddy field. The selection of the location was based on the visual interpretation of remote sensing images and field investigation. The study area where the samples were collected covered an area of $20 \mathrm{~km}^{2}$. The layout of the soil sampling design was pursued by the intersection method, where the first sample point was taken from the center of the land use type as intersection point, and other the five sample midpoints of the intersection was taken linearly at the distance of $1 \mathrm{~km}$ from one another to the edges of the land use type. Soil samples were taken from $0-20 \mathrm{~cm}$ and $20-40 \mathrm{~cm}$ at each of the six locations of the land use type, making a total of 48 samples. During the soil sampling, core samples were taken from the depth of $0-20 \mathrm{~cm}$ and $20-40 \mathrm{~cm}$ using soil sample rings with $100 \mathrm{ml}$.

The core samples were excavated, then weighed before and after oven drying at $105^{\circ} \mathrm{C}$ in the laboratory to determine the bulk density and soil moisture content [29]. The core samples were excavated, then weighed fresh and weighed again after oven drying at $105^{\circ} \mathrm{C}$ in the laboratory to determine the bulk density and soil 
moisture content. Other soil samples were collected in the plastic zip-lock bags, labeled and then transported to the Sokoine University soil laboratory for further processing and analysis.

\section{Soil samples analysis}

Soil samples were analyzed in the soil laboratory unit at Sokoine University of Agriculture (SUA), Tanzania. Before the laboratory analysis, the soil samples were air-dried and sieved with $2 \mathrm{~mm}$ diameter stainless steel sieve to remove stones, roots and large particles. The soil properties considered in this study were soil moisture content, bulk density (BD), water stable aggregates (WSA), total organic matter (TOM), total nitrogen (TN), soil $\mathrm{pH}$, total phosphorus (TP), and cation exchange capacity (CEC). The core samples were excavated, then weighed fresh and weighed again after oven drying at $105^{\circ} \mathrm{c}$ in the laboratory to obtain BD and soil moisture content [29]. The wet sieving method of Kemper \& Koch, (1966) was used with a set of sieves of 4.75, 2.0, 0.5, 0.25 and $0.212 \mathrm{~mm}$ diameter. Approximately, $25 \mathrm{~g}$ of soil sieved through $8 \mathrm{~mm}$ and retained on $5 \mathrm{~mm}$ sieve was put on the first sieve of the set and gently moistened to avoid a sudden rupture of soil aggregates. The set was sieved in distilled water at 30 oscillations per minute for 10 minutes, and the resistant aggregate on each sieve was dried at $105^{\circ} \mathrm{C}$ for 24 hours, It was then weighted and corrected for sand fraction by adding $100 \mathrm{ml}$ of $0.5 \%$ sodium hexametaphosphate and shaking in the shaker machine for 24 hours to obtain the proportion of the true aggregates. The mass of $<0.212$-mm fraction was obtained by difference. The method of Kemper and Rosenau (1986) was used to determine water stable aggregates (WSA \%) by using the Equation as follows

$$
W S A=\frac{\left(M_{(a+s)}-M_{s}\right)}{\left(M_{t}-M_{s}\right)} \times 100
$$

Where $M_{(a+s)}$ is the mass of resistant aggregates plus sand (g); $M_{s}$ is the mass of the sand fraction alone $(\mathrm{g})$ and $M_{t}$ is the total mass of the sieved soil (g).
The model of van Bavel (1949) as modified by Kemper and Rosenau (1986) used to determine the mean Diameter (MWD) of wet-stable aggregates. Thus,

$$
\text { Mean Weight Diameter: } M W D=\sum X_{i} W_{i}
$$

Where: $\mathrm{X}_{\mathrm{i}}=$ Mean diameter of each size fraction $(\mathrm{mm}) ; \mathrm{W}_{\mathrm{i}}=$ Proportion of the total mass in the corresponding size fraction after deducting the weight of stones as indicated above

SOC was determined by Walkle and Black wet oxidation method [30]. The total organic matter (\%) (TOM) was obtained by employing the formula of $1.724 \times$ Organic Carbon (\%). TN was determined by the Kjeldahl process [31]. Soil pH was determined potentiometrically in a slurry system using electronic $\mathrm{pH}$ meter as suggested by [32]. The soil: water slurry was prepared by the ratio of 1:2.5 (weight/volume) to determine soil $\mathrm{pH}$. The determination of total phosphorus (TP) was made using the Bray and Kurtz-1 method [33] for the soils with $\mathrm{pH}$ water less than 7 and Olsen method for soils with $\mathrm{pH}$ water above 7 [34]. The cation exchange capacity of the soil (CEC) was determined by saturating the soil with neutral 1M NHOAc (ammonium acetate) and the adsorbed $\mathrm{NH} 4+$ were displaced using $1 \mathrm{M} \mathrm{KCl}$.

\section{Soil statistical analysis}

The relationship between different physical and chemical properties of soil samples mentioned as dependent variables and, land use type and soil depth as independent variables were statistically tested. From each land use type, twelve samples, six from each soil depth were taken for the computation. The data were analyzed by the Statistical Package for Social Scientists (SPSS version 22) using two ways ANOVA analysis followed by Post Hoc Test of Least Significance Difference (LSD), depending on whether the normality assumptions were met. Differences of means were calculated to compare significant effects at the alpha value of $5 \%$. Furthermore, a Pearson correlation was carried out to explore the relationship between every single property of soil and the other eight parameters considered in the analysis of this study.

\section{Results and Discussion}

Land use change effects on the chemical soil properties

\begin{tabular}{|c|c|c|c|c|c|c|c|c|c|c|c|c|}
\hline & \multicolumn{3}{|c|}{ Forest } & \multicolumn{3}{|c|}{ Upland Cultivation } & \multicolumn{3}{|c|}{ Wetland } & \multicolumn{3}{|c|}{ Rice farm } \\
\hline & $0-20 \mathrm{~cm}$ & $20-40 \mathrm{~cm}$ & $0-40 \mathrm{~cm}$ & $0-20 \mathrm{~cm}$ & $20-40 \mathrm{~cm}$ & $0-40 \mathrm{~cm}$ & $0-20 \mathrm{~cm}$ & $20-40 \mathrm{~cm}$ & $0-40 \mathrm{~cm}$ & $0-20 \mathrm{~cm}$ & $20-40 \mathrm{~cm}$ & $0-40 \mathrm{~cm}$ \\
\hline $\mathrm{pH}$ & 6.4 & 6.17 & 6.29 & 6.44 & 6.42 & 6.43 & 5.2 & 5.48 & 5.32 & 5.73 & 6.1 & 5.92 \\
\hline TOM (\%) & 40 & 43.7 & 41.63 & 24 & 15.2 & 19.7 & 66 & 63 & 64.6 & 19.5 & 12 & 16 \\
\hline TN (g/kg) & 1.9 & 1.07 & 1.47 & 2 & 0.93 & 1.4 & 3.7 & 2.71 & 3.18 & 1.21 & 0.7 & 1 \\
\hline $\mathrm{TP}(\mathrm{mg} / \mathrm{kg})$ & 2.5 & 1.35 & 1.9 & 65 & 58.8 & 62.1 & 15 & 13.7 & 14.5 & 17.4 & 15.7 & 16.55 \\
\hline $\mathrm{CEC}\left(\mathrm{CmolKg}^{-1}\right)$ & 7.9 & 6.5 & 7.18 & 7 & 6.05 & 6.56 & 153 & 13.1 & 14 & 6.58 & 5 & 6 \\
\hline
\end{tabular}

Table 1: Selected soil chemical properties under different land use type and soil depth in the Kilombero valley floodplain, Southeastern Tanzania.

\begin{tabular}{|c|c|c|c|c|c|c|c|c|c|c|}
\hline & \multicolumn{2}{|c|}{ pH } & \multicolumn{2}{|c|}{ TOM (\%) } & \multicolumn{2}{|c|}{ TN(g/kg) } & \multicolumn{2}{|c|}{ TP (mg/kg) } & \multicolumn{2}{|c|}{ CEC $\left(\mathrm{CmolKg}^{-1}\right)$} \\
\hline & $\begin{array}{l}\text { Land Use } \\
\text { Type }\end{array}$ & $\begin{array}{c}\text { Soil } \\
\text { Depth }\end{array}$ & $\begin{array}{l}\text { Land Use } \\
\text { Type }\end{array}$ & $\begin{array}{c}\text { Soil } \\
\text { Depth }\end{array}$ & $\begin{array}{l}\text { Land Use } \\
\text { Type }\end{array}$ & $\begin{array}{c}\text { Soil } \\
\text { Depth }\end{array}$ & $\begin{array}{l}\text { Land Use } \\
\text { Type }\end{array}$ & $\begin{array}{c}\text { Soil } \\
\text { Depth }\end{array}$ & $\begin{array}{l}\text { Land Use } \\
\text { Type }\end{array}$ & Soil Depth \\
\hline $\mathrm{F}$ & 15.33 & 0.75 & 8.93 & 0.263 & 18.9 & 12.74 & 9.9 & 0.32 & 19.31 & 2.77 \\
\hline
\end{tabular}

Table 2: Mean and significance level of selected soil chemical properties in the Kilombero valley floodplain, southeastern Tanzania. 


\section{International Journal of Environmental Sciences \& Natural Resources}

\begin{tabular}{|c|c|c|c|c|c|c|c|c|c|c|}
\hline P & $.001^{*}$ & 0.393 & $.001 *$ & 0.611 & $.001^{*}$ & $.001^{*}$ & $.001 *$ & 0.577 & $.001^{*}$ & 0.104 \\
\hline $\begin{array}{c}\text { Mean } \\
\text { (n- } \\
48)\end{array}$ & \multicolumn{4}{|c|}{35.46} & \multicolumn{2}{|c|}{1.75} & \multicolumn{2}{|c|}{22.71} & \multicolumn{2}{|r|}{8.38} \\
\hline
\end{tabular}

The soil chemical properties were different under different land use type in different soil depth (Table 1). Soil pH was low in the wetland area; TN, TOM, and CEC were low in the rice farm whereas TP was observed to be low in the forest area. A two-way analysis of variance (ANOVA) was conducted to explore the impact of different land use type (forest, wetland, rice farm and upland cultivation) and soil depths $(0-20 \mathrm{~cm}, 20-40 \mathrm{~cm})$ on soil chemical property parameters (soil $\mathrm{pH}$, total Nitrogen, soil organic matter, total Phosphorous and Cation Exchange Capacity) status. Results revealed there was a significant difference $(\mathrm{P}<0.05)$ for soil $\mathrm{pH}$, TN, TOM, TP and CEC under different land use types. However, there was no significantly different for selected soil chemical property parameters between the two depths $(0-20 \mathrm{~cm}, 20-40 \mathrm{~cm})$, with the exception of TN (Table 2).

\section{Soil pH}

Soil pH is a measurement of soil acidity and alkalinity [35], thereby representing the $\mathrm{H}+$ concentration in the soil solution. Soils collected from the four land use types showed that the highest soil $\mathrm{pH}$ (average) was found in the upland cultivation a $\mathrm{pH}$ value of 6.43 , followed by forest with value of 6.29 then, rice farm with value of 5.92 while the lowest $\mathrm{pH}$ was found in wetland with a pH value of 5.32 (Figure 3). The acidic condition of the upland cultivation and rice farm is due to organic and inorganic fertilizer application by the farmers. Interview with local farmers revealed that most farmers apply inorganic fertilizers at a rate of $20-42 \mathrm{~kg}$ $\mathrm{N}$ and $10-15 \mathrm{~kg} \mathrm{P} \mathrm{ha-1}$ per year in the rice farms. Moreover, the multivariate analysis of variance (ANOVA) showed that for soil $\mathrm{pH}$, there is the statistically significant difference at $\mathrm{P}<0.05$ level among land use types: $\mathrm{F}(3,40)=15.33, \mathrm{P}=0.001$ while there was no significant difference between soil $\mathrm{pH}$ and soil depth (Table 2). The Post Hoc Test of LSD revealed that there is statistically significant difference at $\mathrm{P}<0.05$ for the soil $\mathrm{pH}$ between wetland and rice farm; forest and wetland, upland cultivation and rice farm; upland cultivation and wetland, whereas the soil $\mathrm{pH}$ difference between forest and upland cultivation was not statistically significant (Table 3). Factors that influencing soil pH include organic matter decomposition, nitrogen fertilizer source, weathering of minerals and parent material, climate, and land management practices [36]. There was no significant difference between forest and upland cultivation due to the land management practice in an upland that enforces the minimum use of inorganic fertilizers in their farms.
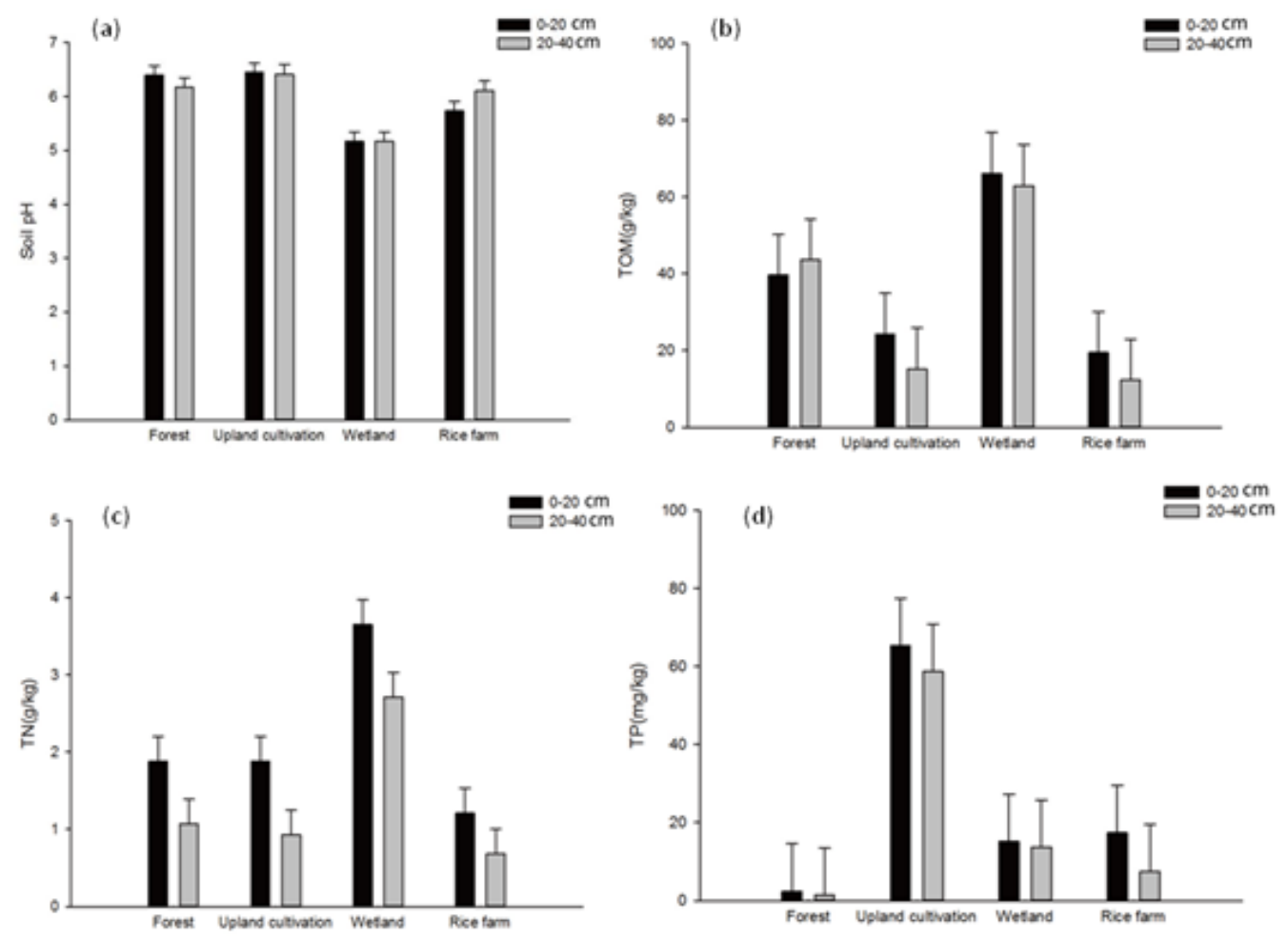

Figure 3: a- Soil pH; b- Total Organic Matter (TOM); c- Total Nitrogen (TN) d- Total Phosphorous (TP) values of soils collected from the forest, upland cultivation, wetland and rice farm in the surface $0-20 \mathrm{~cm}$ and subsurface $20-40 \mathrm{~cm}$ layers. Bars represent standard errors. 


\section{International Journal of Environmental Sciences \& Natural Resources}

Table 3: Two-way ANOVA multiple comparisons for different soil chemical properties among land use types in the Kilombero valley floodplain, southeastern Tanzania

\begin{tabular}{|c|c|c|c|c|c|c|}
\hline \multirow{2}{*}{ Soil Properties } & \multirow{2}{*}{ Land Use Type (I) } & \multirow{2}{*}{ Land Use Type (J) } & \multirow{2}{*}{ Mean Difference (I-J) } & \multirow{2}{*}{ sig } & \multicolumn{2}{|c|}{ 95\% Confidence Interval } \\
\hline & & & & & Lower Bound & Upper Bound \\
\hline \multirow{3}{*}{$\mathrm{pH}$} & Forest & Wetland & $.961^{*}$ & 0.001 & 0.48 & 1.438 \\
\hline & Upland cultivation & Wetland & $1.106^{*}$ & 0.001 & 0.63 & 1.583 \\
\hline & Wetland & Rice farm & $-.596^{*}$ & 0.01 & -1.1 & -1.186 \\
\hline \multirow{3}{*}{$\mathrm{TN}(\mathrm{g} / \mathrm{kg})$} & Forest & Wetland & $-1.710^{*}$ & 0.001 & -2.6 & -0.853 \\
\hline & Wetland & Rice farm & $2.238^{*}$ & 0.001 & 1.38 & 3.096 \\
\hline & Wetland & Upland cultivation & $1.780^{*}$ & 0.001 & 0.92 & 2.638 \\
\hline $\mathrm{TP}(\mathrm{mg} / \mathrm{kg})$ & Forest & Upland cultivation & $-10.459 *$ & 0.001 & -93 & -27.89 \\
\hline \multirow[t]{2}{*}{$\mathrm{CEC}\left(\mathrm{CmolKg}^{-1}\right)$} & Upland cultivation & Wetland & $-7.458^{*}$ & 0.001 & -11 & -4.182 \\
\hline & Wetland & Rice farm & $8.328^{*}$ & 0.001 & 4.96 & 11.514 \\
\hline
\end{tabular}

\section{Total organic matter (TOM)}

Total organic matter is the combination of plant and animal residues at various stages of decomposition, and cells and tissues of soil organisms [37]. The multivariate analysis of variance (ANOVA) revealed that TOM was significantly different at $\mathrm{P}<0.05$ by different land use change; $\mathrm{F}(3,40)=8.93, \mathrm{P}=0.001$ while there was no significant difference between TOM and soil depth (Table 2 ). The highest TOM content was found in the wetland $64.56 \%$, followed by the forest $41.63 \%$, upland cultivation $19.74 \%$ and the lowest TOM content was found in the rice farm 15.8\% (Table 1 \& Figure 3). The high content of TOM in the wetland is attributed to the higher clay content which forms clay humus complexes that protect the OM against oxidation and degradation. Clay particles also act as an adsorption sink of OM [38], therefore the increase in clay contributed to the high content of OM in the wetland soil. In the forest decay of tree leaves, stems, barks, flowers, logs microorganisms, animals, trees roots and fruits increase OM. On the other hand, upland cultivation and rice farm had low TOM content. The deterioration of TOM in upland cultivation and rice farm may be due to the removal of biomass during cultivation, a low quantity and quality $\mathrm{C}$ inputs to the soil combined with faster OM decomposition and mineralization rates [13,39]. In addition, continuous tillage and use of machinery during cultivation may cause periodically breakup of the macroaggregates, increases soil aeration and expose previously protected OM [40]. Soil organic matter is considered to influence total nitrogen, available phosphorus, CEC and other chemical and physical properties [41]. The Post Hoc Test of LSD revealed that there is a statistically significance difference at $\mathrm{P}<0.05$ for the TOM between wetland and rice farms (Table 3).

\section{Total nitrogen (TN)}

The multivariate analysis of variance (ANOVA) showed that TN was significantly affected $(\mathrm{P}<0.05)$ by different land use change and soil depth. There was a significant difference between land use type and TN content; $\mathrm{F}(3,40)=18.90, \mathrm{P}=0.001$. Similarly, there was a significant difference between TN content and soil depth; $F(3,40)=12.74, \mathrm{P}=0.001$ (Table 2). TN showed similar trend as TOM, whereas the highest TN was found in the wetland with an average range of values of $3.18 \mathrm{~g} / \mathrm{kg}$, followed by forest with TN value of $1.47 \mathrm{~g} / \mathrm{kg}$, then upland cultivation with TN value of $1.4 \mathrm{~g} / \mathrm{kg}$ and finally the rice farm had TN value of $1.00 \mathrm{~g} /$ $\mathrm{kg}$, Figure 3 (Table 1). It has been reported by other studies that the organic/inorganic amendments or their combination application in cultivated land have significantly increased TN [42]. The reduction of $\mathrm{TN}$ in upland cultivation and rice farm may be due to cultivation practices such as tillage practices that reduced soil nitrogen content by exposing the soil to more air that bacteria need, comparing to non-tillage practices $[43,44]$. Moreover, TN is decreasing with soil depth. TN of the four land use types at two depths indicated that surface $0-20 \mathrm{~cm}$ layer had significantly more TN than subsurface $20-40 \mathrm{~cm}$ layer (Table 2), showing a relative increase of $31,51,56$, and $76 \%$ in wetland, rice farm, forest, and upland cultivation, respectively.

\section{Total phosphorus (TP)}

Analysis of variance revealed that TP was the significant difference at $\mathrm{P}<0.05$ by different land use change; $\mathrm{F}(3,40)=9.90$, $\mathrm{P}=0.001$ while there was no significant difference between TP and soil depth (Table 2). The highest TP was found in the upland cultivation with the value of $62.1 \mathrm{mg} / \mathrm{kg}$, followed by rice farm with 
value of $16.5 \mathrm{mg} / \mathrm{kg}$, then wetland with the value of $14.5 \mathrm{mg} / \mathrm{kg}$ and finally the lowest TP was found in the forest with a value of $1.9 \mathrm{mg} / \mathrm{kg}$, Figure 3. Despite high soil $\mathrm{pH}$ and TOM in the forest area, TP value appears to be low due to the parent soil type of Umbric Nitisol, which is characterized by low level available phosphorous [45]. The high value of TP in upland cultivation compared to other land uses is due to the application of organic and inorganic fertilizers. It has been reported by key informant interviews that the use of manure has significantly increased TP throughout the study area [46]. Moreover, the presence of phosphorus content depends upon a number of factors such as climate, vegetation, soil texture, land use pattern, fertilizer use, drainage, irrigation, and soil $\mathrm{pH}$, whereby the availability of phosphorus is greatest in the soil pH range 6.0-6.5 [47]. The Post Hoc Test of LSD revealed that there is statistically significance difference at $\mathrm{P}<0.05$ for the TP between forest and upland cultivation; upland cultivation and rice farm; upland cultivation and wetland, whereas the TP difference between wetland and rice farm was not statistically significant (Table 3).

\section{Cation exchange capacity (CEC)}

The cation exchange capacity (CEC) is a measure of the number of adsorption sites per unit weight of soil at a particular $\mathrm{pH}$ [47]. The multivariate analysis of variance (ANOVA) showed that for CEC that there is a statistical significance difference at $\mathrm{P}<0.05$ level among land use types: $\mathrm{F}(3,40)=19.31, \mathrm{P}=0.001$ while there was no significant difference between CEC and soil depth (Table 2). CEC was high in the wetland with the value of $14 \mathrm{CmolKg}^{-1}$, followed by forest $7.18 \mathrm{CmolKg}^{-1}$, then upland cultivation with the value of $6.56 \mathrm{CmolKg}^{-1}$ and lastly rice farm with the value of $6.00 \mathrm{CmolKg}^{-1}$ (Figure 4; Table 1). This is due to the difference in TOM and clay content under different land use types.

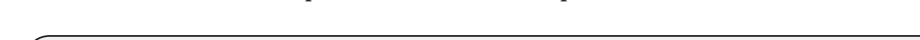

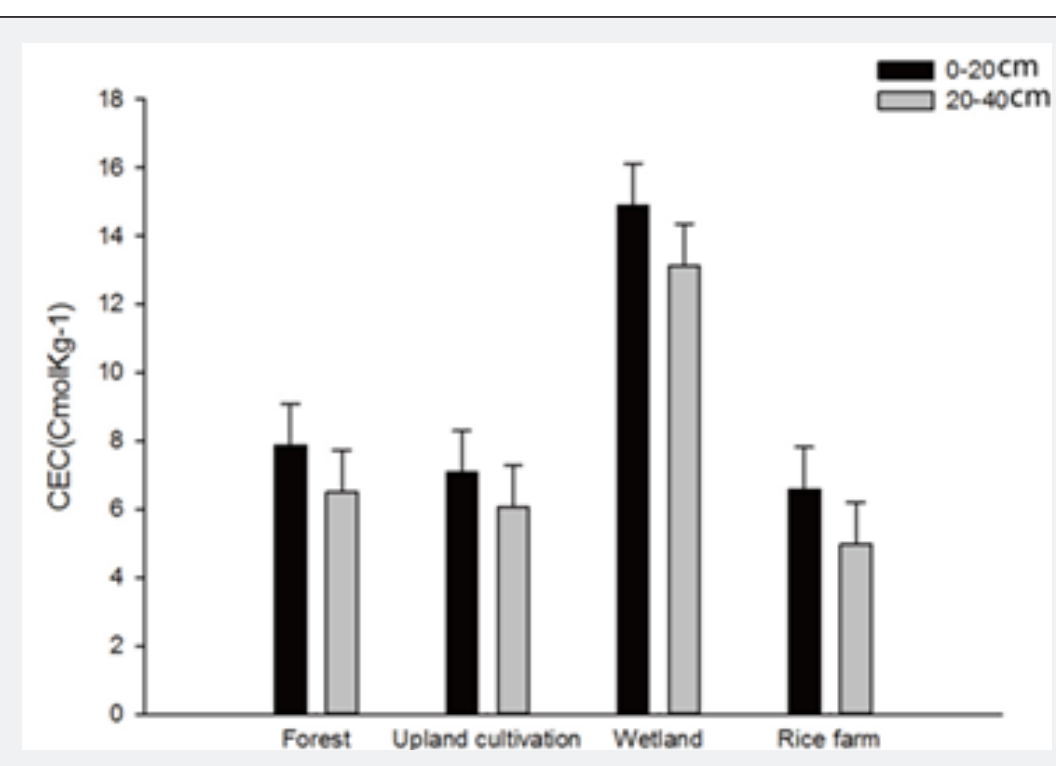

Figure 4: Cation Exchange Capacity (CEC) values of soils collected from the forest, upland cultivation, wetland and rice farm in the surface $0-20 \mathrm{~cm}$ and subsurface $20-40 \mathrm{~cm}$ layers. Bars represent standard errors.

Generally, the CEC of soils is determined by their TOM content and the amount and type of clay minerals present in the soil [48]. The low CEC in rice farm and upland cultivation in the study area is due to low TOM, which is attributed to the cultivation practices that expose previously protected TOM. The high CEC in wetland and forest in the study area is due to high TOM and clay content in these land use type. The Post Hoc Test of LSD revealed that there is a statistical significance difference at $\mathrm{P}<0.05$ level for the CEC between forest and wetland; upland cultivation and wetland; wetland and rice farm, whereas the CEC difference between forest and upland cultivation was not statistically significant (Table 3).

\section{Land use change effects on the physical soil properties}

The soil physical properties were different under different land use type (Table 4). Mean bulk density (BD) was low in wetland while it was high in the forest area. A two-way analysis of variance (ANOVA) was conducted to explore the impact of differ- ent land use type (forest, wetland, rice farm and upland cultivation) and soil depths $(0-20 \mathrm{~cm}, 20-40 \mathrm{~cm})$ on soil physical property parameters (BD, Soil Moisture Content (SMC) and Mean Weighted Diameter (MWD)) status. Results revealed there was a significant difference $(\mathrm{p}<0.05)$ for BD, Soil Moisture Content (SMC) and Mean Weighted Diameter (MWD)) under different land use types. Moreover, there was significantly different for selected soil physical parameters between the two depths $(0-20 \mathrm{~cm}, 20-40 \mathrm{~cm})$, with the exception of the Soil Moisture Content (SMC) (Table 5).

\section{Bulk density (BD)}

Bulk density refers to the weight of dry soil per unit of volume, more compacted soil with less pore space will have a higher bulk density [49]. The multivariate analysis of variance (ANOVA) showed that BD had significantly affected at $\mathrm{P}<0.05$ by different land use types and soil depth (Table 4). The analysis showed for $\mathrm{BD}$ that there is a statistical significance difference at $\mathrm{P}<0.05$ level 
among land use types: $F(3,40)=4.90, P=0.005$. Similarly, there was significant different between $\mathrm{BD}$ and soil depths $(0-20 \mathrm{~cm}$; $20-40 \mathrm{~cm}$ ); $\mathrm{F}(3,40)=4.22, \mathrm{P}=0.047$ (Table 5 ). The highest BD value was found in upland cultivation with $1129 \mathrm{~kg} / \mathrm{m}^{3}$, followed by rice farm with $1211 \mathrm{~kg} / \mathrm{m}^{3}$, then forest land with $1041 \mathrm{~kg} / \mathrm{m}^{3}$, lastly the lowest BD was found in the wetland with $950 \mathrm{~kg} / \mathrm{m}^{3}$ (Figure 5). The soil in forest and wetland were observed to have low bulk density owing to the fact that they have well-aggregated soil and high organic matter compared to other land use types. On the other hand, in upland cultivation and rice farm observed to have high bulk density, which is attributed to intensive cultivation practices that reduced porosity, soil aggregate, and soil organic matter. Similarly, Moreover, bulk density showed an increased trend with soil depth (Table 4). This is because subsurface layers have reduced organic matter, aggregation and root penetration compared to the surface layers, thus contain less pore space hence high bulk density [50]. The Post Hoc Test of LSD revealed that there is the statistical significance difference at $\mathrm{P}<0.05$ level for the $\mathrm{BD}$ between wetland and rice farm (Table 6).

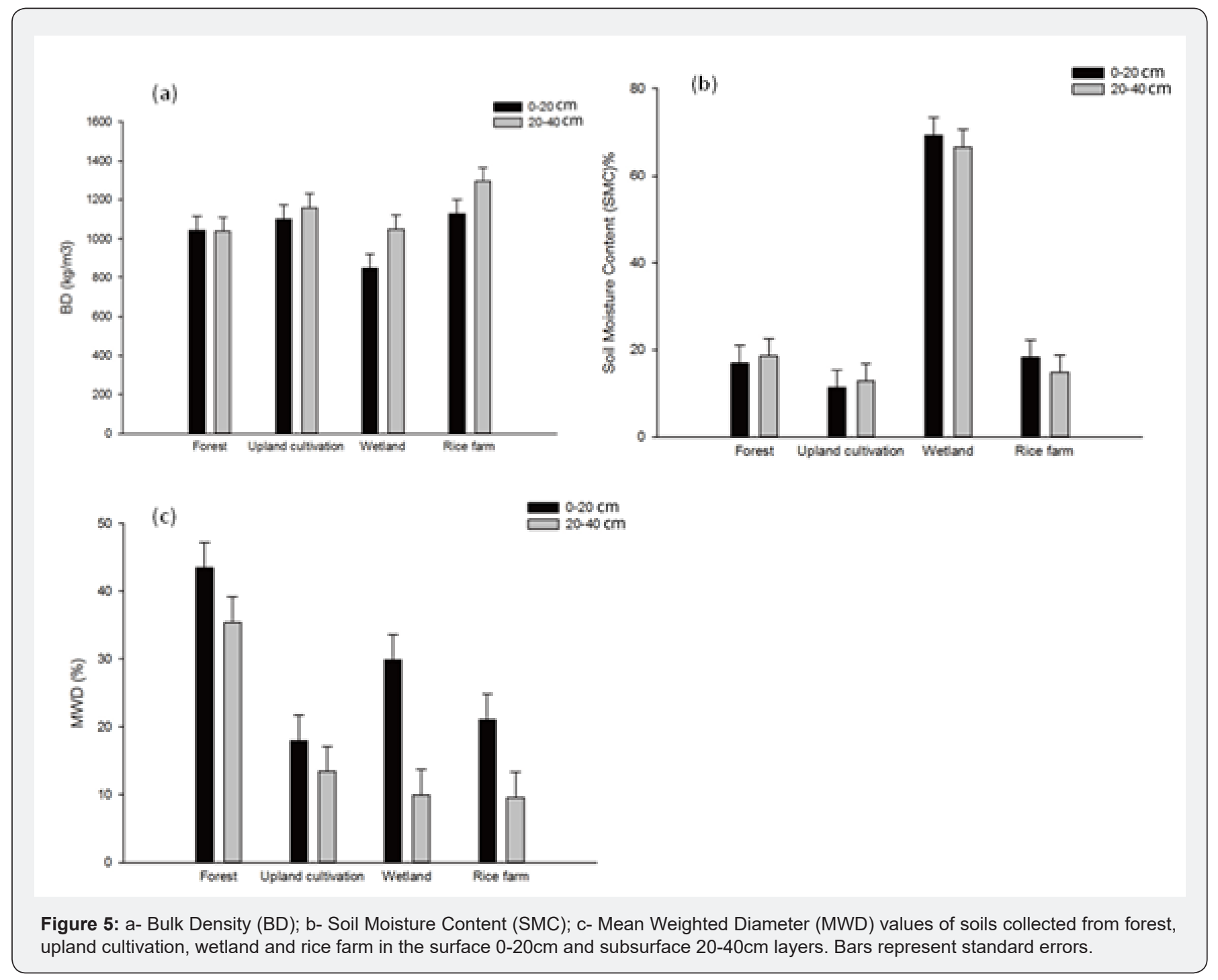

Table 4: Selected soil physical properties under different land use type and soil depth in the Kilombero valley floodplain, Southeastern Tanzania (Mean, std error, $n=48$ )

\begin{tabular}{|c|c|c|c|c|c|c|c|c|c|c|c|c|}
\hline & \multicolumn{3}{|c|}{ Forest } & \multicolumn{3}{|c|}{ Upland Cultivation } & \multicolumn{3}{|c|}{ Wetland } & \multicolumn{3}{|c|}{ Rice Farm } \\
\hline & $0-20 \mathrm{~cm}$ & $20-40 \mathrm{~cm}$ & $0-40 \mathrm{~cm}$ & $0-20 \mathrm{~cm}$ & $20-40 \mathrm{~cm}$ & $0-40 \mathrm{~cm}$ & $0-20 \mathrm{~cm}$ & $20-40 \mathrm{~cm}$ & $0-40 \mathrm{~cm}$ & $0-20 \mathrm{~cm}$ & $20-40 \mathrm{~cm}$ & $0-40 \mathrm{~cm}$ \\
\hline $\mathrm{BD}\left(\mathrm{kg} / \mathrm{m}^{3}\right)$ & 1044 & 1038 & 1041 & 1100 & 1158 & 1129 & 850 & 1050 & 950 & 1129 & 1294 & 1211 \\
\hline MWD (\%) & 43.43 & 35.4 & 39.4 & 17.9 & 13.4 & 15.7 & 29.8 & 9.9 & 20 & 21.1 & 9.57 & 15.3 \\
\hline
\end{tabular}




\section{International Journal of Environmental Sciences \& Natural Resources}

Table 5: Mean and significance level of selected soil physical properties in the Kilombero valley floodplain, southeastern Tanzania.

\begin{tabular}{|c|c|c|c|c|c|c|}
\hline \multirow{2}{*}{} & \multicolumn{2}{|c|}{ BD } & \multicolumn{2}{c|}{ SMC (\%) } & \multicolumn{2}{c|}{ MWD (\%) } \\
\cline { 2 - 7 } & Land use type & Soil depth & Land use type & Soil depth & Land use type & Soil depth \\
\hline F & 4.9 & 4.22 & 84.32 & 0.07 & 18.32 & 17.02 \\
\hline P & $.005^{*}$ & $0.047^{*}$ & $.001^{*}$ & 0.794 & $.001^{*}$ & $.001^{*}$ \\
\hline Mean (n-48) & \multicolumn{2}{|c|}{1082.99} & \multicolumn{2}{|c}{28.54} & \\
\hline
\end{tabular}

\section{Soil moisture content (SMC)}

SMC refers to the ratio of the mass of water present in a soil sample to the mass of the sample after it has been dried at $105^{\circ} \mathrm{C}$ to a constant weight [14]. Results showed that the highest value of SMC was found in the wetland with $68 \%$, followed by forest with SMC value of $17.7 \%$, then rice farm with $16.5 \%$ while the lowest SMC was found in the upland cultivation with $12.0 \%$ (Figure 5). The multivariate analysis of variance (ANOVA) for SMC indicated that there is a statistical significance difference at $\mathrm{P}<0.05 \mathrm{lev}-$ el among land use types: $\mathrm{F}(3,40)=84.32, \mathrm{P}=0.001$ while there was no significant difference between SMC and soil depth (Table 4). The decreased SMC in rice farm and upland cultivation is due to cultivation and tillage practices that increased pores, creating more aeration exposing the soil to evaporation and making it dry. SMC as a dependent variable using the Least Significance Difference (LSD) test shows that there is a significant difference at $\mathrm{P}<0.05$ for the SMC between wetland and rice farms (Table 6).

\section{Water stable aggregate (WSA)}

The aggregate stability is the ability of the bonds of the aggregates to resist when exposed to stresses such as tillage, water and/or wind erosion causing their disintegration, measured by mean weighted diameter (MWD) [40]. The results showed that the highest MWD value was found in the forest (39.4\%), followed by wetland (20\%), then upland cultivation (15.7\%), lastly in the rice farm (15.3\%) (Figure $5 \&$ Table 4). This shows that MWD decreased as forest and wetland are converted to upland cultivation and rice farm, respectively. Significantly decreased in MWD at $\mathrm{P}<0.05$ was observed when forest converted to upland cultivation. These are due to loss of $\mathrm{OM}$, removal of vegetation that leaves the soil bare and tillage practices that cause the breakdown of large aggregates into smaller aggregates in the soil hence reduced soil stability. Moreover, tillage practices tend to rapidly destroy plant roots, fungal hyphae, earthworms, and termites, which favors the formation of larger-sized aggregates in the soil [40]. The multivariate analysis of variance (ANOVA) showed that there was significant difference between MWD and land use type; F $(3,40)=18.32$, $\mathrm{P}=0.001$. Similarly, there was significant difference between MWD and soil depth; $F(3,40)=17.02, P=0.001$ (Table 5). MWD showed a decreased trend with soil depth (Table 4). MWD as a dependent variable using the Least Significance Difference (LSD) test shows that there is a significant difference at $\mathrm{P}<0.05$ for the MWD between forest and upland cultivation, forest and rice farm (Table 6). Similarly, $[8,15,51]$ observed that the size distribution of aggregates is affected by the change in land use and management.

\section{Pearson correlation of physical and chemical soil prop- erties}

A Pearson correlation was carried out to explore the relationship between each single properties of soil and the other 8 parameters considered in the analysis of this study. The correlation between total organic matter (TOM) and total nitrogen (TN) showed a strong positive partial correlation, $r=0.751, n=48, p$ $<0.01$. Moreover, there was very strong positive correlation between TN and CEC, $\mathrm{r}=0.831, \mathrm{n}=48, \mathrm{p}<0.01$, and between TOM and CEC, $r=0.736, n=48, p<0.01$, however, TN was strong negatively correlated with BD, $r=-0.749$. This result concurred with the findings of [8] who studied the soils in northwestern Ethiopia. Moreover, this is also in line with the other studies $[8,15,17]$ that conversion of forest and wetland to agricultural land had lead to declined TOM, and that TOM influence $\mathrm{N}$ in the soil, soil available phosphorus (TN), and CEC. In addition, there was a strong negative significant correlation between BD and CEC $(r=0.739, \mathrm{n}=$ 48, $\mathrm{p}<0.01$ ) and BD and TOM ( $\mathrm{r}=-0.631, \mathrm{n}=48, \mathrm{p}<0.01$ ) (Table $7)$. On the contrary, a strong positive correlation was also noted between SMC and, TN, TOM and CEC where $r=0.742,0.620$, and 0.812 respectively (Table 7 ). The total phosphorus has shown a positive significant correlation with soil $\mathrm{pH}$ at $(\mathrm{r}=0.329, \mathrm{n}=48$, $\mathrm{p}<0.05$ ) (Table 7), this shows that CEC depends upon the $\mathrm{pH}$ of the soil.

\section{Conclusion}

The study was conducted to investigate the impact of agricultural land use change on soil physico-chemical properties. The study concluded that the magnitude of some soil quality parameters varies with depth in different land use types. Bulk density increased with depth due to compaction and decreasing organic matter content and reduced aggregation with depth. Moreover, agricultural land use change in the study area has impacted the soil conditions. Soils found in the wetland and forests were observed to have high concentration of nutrients and good physical properties. In contrary, soils in agricultural land both upland cultivation and rice farm showed sub-sequential decreased in soil organic matter, total nitrogen (TN), cation exchange capacity (CEC), soil moisture content (SMC) and soil aggregate stability. The low organic matter in agricultural land may be due to low inputs coupled with reduced physical protection of TOM as a result of the burning of crop residues, tillage and oxidation of soil organic matter. These low TOM and CEC under agricultural land have negatively affected physical properties of the soil particularly, the aggregate stability in the highland areas where the forest has been convert- 
ed into upland cultivation. However, bulk density, soil $\mathrm{pH}$ and total phosphorus (TP) increased following these agricultural land use change. The significant difference between physical and chemical soil properties was observed when the wetland is converted to rice farm showing that wetland area is highly sensitive to declined soil fertility. These results highlight that the conversion of pristine vegetation (forest and wetland) into agricultural land has an effect on the soil fertility and physical conditions in the Kilombero valley floodplain, southeastern Tanzania that requires establishment of the proper agricultural practices that will effectively restore the lost soil nutrients particularly, TOM. Therefore, this study recommends the imposition of agricultural practices to the smallholder farmers such as agroforestry, incorporation of crop residues, use of organic manures, minimum tillage, and crop rotation that facilitates soil organic matter building up. These can improve the concentration of physical, chemical, and biological soil parameters in the agricultural land. Moreover, to reduce the encroachment of farmers into wetland and forest area serious attention should be given to the development of sustainable land use planning and management in the Kilombero valley floodplain.

\section{Policy Implications}

Author Contributions: N.K.M. designed the study, analyzed the data, and prepared the manuscript with contributions from J.L who contributed to the conceptualization of ideas, the methodology and the review of the manuscript.

Funding: This research was funded by [the Foundation of Jilin Educational Committee] grant number [JJKH20180024KJ]; [the National Key Research and Development Program of China] grant number [2016YFC0500407].

Acknowledgment: Nangware Kajia Msofe is thankful to the above-mentioned funding agents in China for providing funds to carry out this research as part of the Ph.D. studies. Sincere thanks also go to her supervisor, Sheng Lianxi for his endless support in carrying out the research and developing the manuscript. The authors are also thanking the technical and field support provided by district officers, managers and farmers in the Kilombero district during the conduct of the research.

\section{References}

1. Lambin EF, HJ Geist (2006) Land-use and land-cover change: Local processes and global impact. Verlag Berlin Heideberg: Springer.

2. Lambin EF, HJ Geist \& E (2003) Lepers Dynamics of Land Use and Land Cover Change in Tropical Regions. Annual Review of Environment and Resources 28: 205-241.

3. Ramsar Convention (1971) The Ramsar Convention, R Center Editor, Rue Mauverney. (28 edn.), CH 1196, Gland, Switzerland.

4. Food and Agriculture Organization F (1997) Agriculture and climate change: FAO role, Viale delle Terme di Caracall: Italy.

5. Dahl TE (1990) Wetlands losses in the United States s to 1980's, FaW Service, US Department of the Interior: Washington DC, USA, p. 1780.

6. Millennium Ecosystem Assessment M (2005) Ecosystems and Human Well-being: General Synthesis. Island Press: Washington DC, USA.
7. Schuyt KD (2005) Economic consequences of wetland degradation for local populations in Africa. Ecological Economics 53(2): 177-190.

8. Selassie YG, G Ayanna (2013) Effects of Different Land Use Systems on Selected Physico-Chemical Properties of Soils in Northwestern Ethiopia. Journal of Agricultural Science 5(4).

9. Selassie YG, F Anemut, S Addisu (2015) The effects of land use types, management practices and slope classes on selected soil physicochemical properties in Zikre watershed, North-Western Ethiopia. Environmental Systems Research 4(1): 3.

10. Kamiri H, C Kreye, M Becker (2013) Dynamics of agricultural use differentially affect soil properties and crop response in East African wetlands. Wetlands Ecology Management 21(6): 417-431.

11. Dixon AB, AP Wood (2003) Wetland cultivation and hydrological management in East Africa: matching community and hydrological needs through sustainable wetland use. Natural Resource Forum 27(2): 117-129.

12. Bahrami A (2010) Land-use change and soil degradation: A case study, North of Iran. Agric Biol J N Am 1(4): 600-605.

13. Wang $Q$ Jingshuang Liu, Yang Wang, Jiunian Guanet, Qiang Liu, et al. (2012) Land use effects on soil quality along a native wetland to cropland chronosequence. European Journal of Soil Biology 53: 114120 .

14. Avnimelech Y, Gad Ritvo, Leon E Meijer, Malka Kochba (2002) Water content, organic carbon and dry bulk density in flooded sediments. Aquacultural Engineering 25(1): 25-33.

15. Abbasi MK, M Zafar, S Razaq Khan (2007) Influence of different landcover types on the changes of selected soil properties in the mountain region of Rawalakot Azad Jammu and Kashmir. Nutr Cycl Agroecosyst 78: $97-110$

16. Islam KR, RR Weil (2000) Land use effects on soil quality in a tropical forest ecosystem of Bangladesh. Agriculture Ecosystems Environment 79(1): 9-16.

17. Ayoubi S (2011) Assessing impacts of land use change on soil quality indicators in a loessial soil in Golestan Province, Iran. Journal of Agricultural Science 13(5): 727-742.

18. Guo YJ, JG Han (2009) The Influence of Land Use Change on Chemical and Biological Properties of Steppe Soils in Northern China. Arid Soil Research Management 23(3): 197-212.

19. Jiang S (2006) The impact of land use on soil properties in a karst agricultural region of Southwest Chinaa case study of Xiaojiang watershed, Yunnan. Environmental Geology 50(01): 911.

20. Ramsar Convention S (2008) The Ramsar List of Wetlands of International Importance, RM 28 (ed.), CH-1196, Gland: Switzerland.

21. Ministry of Natural Resources and Tourism M (2007) The National Wetlands Management Strategy: Dares Salaam, Tanzania, East Africa.

22. Msofe NK, L Sheng, J Lyimo (2019) Land Use Change Trends and Their Driving Forces in the Kilombero Valley Floodplain, Southeastern Tanzania. Sustainability 11: 505.

23. Wilson E, et al. (2017) Ramsar Advisory Mission Report; Ramsar Site No. 1173, Kilombero Valley, United Republic of Tanzania: Dar es Salaam, Tanzania.

24. Jätzold R, E Baum (1968) The Kilombero Valley, Weltforum: Munich, Germany.

25. Leemhuis C (2017) Sustainability in the Food-Water-Ecosystem Nexus: The Role of Land Use and Land Cover Change for Water Resources and Ecosystems in the Kilombero Wetland, Tanzania. Sustainability 9: 1513. 
26. Muro J, et al. (2017) 25 years of landscape changes in the Kilombero floodplain, Tanzania, in Worldcover 2017 Conference, European Space Agency-ESRIN: Frascati (Rome), Italy.

27. Bonnington C, D Weaver, E Fanning (2007) Livestock and large wild mammals in the Kilombero Valley, in southern Tanzania. African Journal of Ecology 45(4): 658-653.

28. Dewitte 0, ArwynJones, Otto Spaargaren, Henrik Breuning-Madsen, et al. (2013) Harmonisation of the soil map of Africa at the continental scale. Geoderma 211: 138-153.

29. Blake GR, KH Hartge (1986) Bulk density In Methods of Soil Analysis, in Part 1: Physical and Mineralogical Methods. ( $2^{\text {nd }}$ edn), SSSA Book Series 5: Madison Wisconsin, Wisconsin.

30. Nelson DW, LE Sommers (1982) Total carbon, organic carbon and organic matter. In: AL RH Miller, DR Keeney (Eds.), Methods of Soil Analysis, Part 2; Chemical and Microbiological Properties, American Society of Agronomy: Madison. pp. 539-579.

31. Bremner JM, C Mulvaney S (1982) Total nitrogen, in Methods of Soil Analysis. Part 2. Chemical and Microbiological Properties. In: Page, Miller RH, Keeney DR (Eds.), American Society of Agronomy: Madison, Wisconsin. pp. 595-624.

32. Mclean E (1982) Soil pH and Lime Requirement, In: Page, AL, (ed.), Methods of Soil Analysis. Part 2. Chemical and Microbiological Properties. American Society of Agronomy, Soil Science Society of America: Madison. pp. 199-224.

33. Bray RH, LT Kurtz (1945) Determination of total organic and available forms of phosphorus in soils. Soil Science 59: 39 -45.

34. Watanabe FS, SR Olsen (1965) Test of an Ascorbic Acid Method for Determining Phosphorus in Water and NaHCO3 Extracts from the Soil. Soil Science Society of America 29(6): 677-678.

35. Doran JW, Sarrantonio M, Liebig M (1996) Soil health and sustainability, in Advances in Agronomy. In: Sparks DL (Ed.), 1996, Academic Press: San Diego, pp. 1-54.

36. Mohammed MY (2017) Impact of land use and management practice on soil physical and chemical quality indicators of Vertisols at Pawe, Northwestern Ethiopia.

37. Schnitzer M, Khan SU (1978) Soil Organic Matter. Elsevier Scientific Publishing Company, New York, NY 10010, USA.

38. Abegaz A (2016) Spatial and temporal dynamics of soil organic carbon in landscapes of the upper Blue Nile Basin of the Ethiopian Highlands Agr Ecosyst Environ (218): 190-208.
39. Murty D, Miko UF Kirschbaum, Ross E Mcmurtrie, Heather Mcgilvray (2002) Does conversion of forest to agricultural land change soil carbon and nitrogen? A review of the literature. Global Change Biol 8(2): 105-123.

40. Six J, ET Elliott, K Paustian (1999) Aggregate and soil organic matter dynamics under conventional and no-tillage systems. Soil Science Society of America Journal 63: 1350-1358.

41. Takoutsing B (2015) Soil chemical properties dynamics as affected by land use change in the humid forest zone of Cameroon. Agroforestry Systems 90(6): 1-14.

42. Duguma LA, H Hager, M Sieghardt (2010) Effects of land use types on soil chemical properties in smallholder farmers of central highland Ethiopia. Ekologia 29(1): 1-14.

43. Mikha MM (2017) Manure and tillage use in remediation of eroded land and impacts on soil chemical properties. Plos One 12(4).

44. Tong C (2009) Long-term fertilizer effects on organic carbon and total nitrogen and coupling relationships of $\mathrm{C}$ and $\mathrm{N}$ in paddy soils in subtropical China. Soil Till Res 106(1): 8-14.

45. ISRIC (2019) Major soils of the world.

46. Willy DK, Muyanga M, Mbuvi J, Jayne T (2019) The effect of land use change on soil fertility parameters in densely populated areas of Kenya. Geoderma 343: 254-262.

47. Hishe S, J Lyimo, W Bewket (2017) Soil and water conservation effects on soil properties in the Middle Silluh Valley, northern Ethiopia. International Soil Water Conservation Research 5(3): 231-240.

48. Bewket W, L Stroosnijder (2003) Effects of agroecological land use succession on soil properties in Chemoga watershed, Blue Nile basin, Ethiopia, Geoderma 111(1-2): 85-98.

49. Abu ST, IU Abubakar (2013) Evaluating the effects of tillage techniques on soil hydro physical properties in Guinea Savanna of Nigeria. Soil \& Tillage Research 126: 159-168.

50. USDA (2008) Soil quality kit, guide for educators. National resources conservation services.

51. Nadal Romero E, et al. (2015) Impacts of land use changes on physical and chemical soil properties in the Central Pyrenees. in EGU General Assembly Conference.

Your next submission with Juniper Publishers will reach you the below assets

- Quality Editorial service

- Swift Peer Review

- Reprints availability

- E-prints Service

- Manuscript Podcast for convenient understanding

- Global attainment for your research

- Manuscript accessibility in different formats

( Pdf, E-pub, Full Text, Audio)

- Unceasing customer service

Track the below URL for one-step submission https://juniperpublishers.com/online-submission.php 